IRA-International Journal of Management \&

Social Sciences

ISSN 2455-2267; Vol.10, Issue 02 (February 2018)

Pg. no. 74-86.

Institute of Research Advances

http://research-advances.org/index.php/RAJMSS

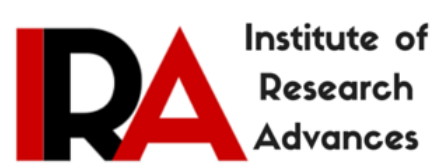

\title{
Effect of Service Quality and Corporate Image Satisfaction and Loyalty of Post Service Users in Regional $X$ Sulawesi and Maluku
}

\author{
Andi Syarifuddin ${ }^{1 \#}$, H. Syahnur Said ${ }^{2}$, H. Annas Plyriadi ${ }^{3}$, Hj. Rastina Kalla ${ }^{4}$ \\ ${ }^{1}$ Economic of High School Science YPUP Moslem University of Indonesia; \\ ${ }^{2,3,4}$ Moslem University of Indonesia.
}

\#corresponding author.

Type of Review: Peer Reviewed.

DOI: http://dx.doi.org/10.21013/jmss.v10.n2.p2

How to cite this paper:

Syarifuddin, A., Said, H.S., Plyriadi, H.A., Kalla, H.R. (2018). Effect of Service Quality and Corporate Image Satisfaction and Loyalty of Post Service Users in Regional X Sulawesi and Maluku. IRA-International Journal of Management \& Social Sciences (ISSN 2455-2267), 10(2), 74-86. doi:http://dx.doi.org/10.21013/jmss.v10.n2.p2

(C) Institute of Research Advances.

\section{(cc) $\mathrm{EY}$-NC}

This work is licensed under a Creative Commons Attribution-Non Commercial 4.0 International License subject to proper citation to the publication source of the work.

Disclaimer: The scholarly papers as reviewed and published by the Institute of Research Advances (IRA) are the views and opinions of their respective authors and are not the views or opinions of the IRA. The IRA disclaims of any harm or loss caused due to the published content to any party.

Institute of Research Advances is an institutional publisher member of Publishers Inter Linking Association Inc. (PILA-CrossRef), USA. The institute is an institutional signatory to the Budapest Open Access Initiative, Hungary advocating the open access of scientific and scholarly knowledge. The Institute is a registered content provider under Open Access Initiative Protocol for Metadata Harvesting (OAI-PMH).

The journal is indexed \& included in WorldCat Discovery Service (USA), CrossRef Metadata Search (USA), WorldCat (USA), OCLC (USA), Open J-Gate (India), EZB (Germany) Scilit (Switzerland), Airiti (China), Bielefeld Academic Search Engine (BASE) of Bielefeld University, Germany, PKP Index of Simon Fraser University, Canada. 


\begin{abstract}
The purpose of this study is to analyze the influence of service quality and corporate image directly to the satisfaction of postal service users, to analyze the influence of service quality and corporate image directly to the loyalty of postal service users, to analyze the direct effect of satisfaction on postal service user loyalty, and to analyze the quality services and corporate image indirectly through the satisfaction of postal service user loyalty. The research was conducted at Regional Post Office X Sulawesi and Maluku with a population of 5,540 people and a sample of 277 respondents based on quota sampling method 5\%. The data of the questionnaire was analyzed using Structural Equation Model using AMOS 18 assistance. The result of the research found that the service quality and the corporate image directly had a positive and significant effect on the satisfaction and loyalty of the postal service users in Regional X Sulawesi and Maluku. Indirectly the image of the company through satisfaction has a positive and insignificant effect on the loyalty of postal service users in Regional $X$ Sulawesi and Maluku, it means that the satisfaction of the postal service users as the intermediate variable cannot be the mediating variable on the influence of corporate image in increasing the loyalty of the postal service users. The overall influence seen from the total effect of the greatest effect is the satisfaction on the loyalty of postal service users, meaning that the higher the customer satisfaction on the service received, the more growing the level of loyalty to use the postal service.
\end{abstract}

Keywords: Quality of Service, Corporate Image, Satisfaction and Loyalty of Postal Service Users

\title{
Preliminary
}

History of the post has existed in Indonesia since 1602 when the VOC controlled the archipelago, which is only done in certain cities on the island of Java and outside Java. Letters or postal parcels are placed in the Stadsherbrg or Town Hall Building, so people always check whether there is a letter or package for it inside the building. Efforts to improve the security of the mail and parcel post, Governor-General GW Baron Van Imhoff established the First Post Office in Indonesia located in Batavia (Jakarta) which was established on August 26, 1746.

The Pos Indonesia Function is an Indonesian State-Owned Enterprise (BUMN) which operates in postal service. Currently, the form of business entity Pos Indonesia is a limited liability company and is often referred to as PT Pos Indonesia. This Postal Form of Indonesia is based on the Government Regulation of the Republic of Indonesia Number 5 Year 1995, this regulation contains the transition of the initial form of Pos Indonesia in the form of public companies (Perum) into a company persero.

Postal service activity in Indonesia, divided by region of Indonesia. There are 11 regions or regional divisions in operation. The division's division covers all provinces in Indonesia. Each division includes one or more provinces that are part of the division. The following is shown regionally in Indonesia.

1. Regional Division I Medan Representative Center (covering Aceh Province and North Sumatra)

2. Regional Division II Representative of Central Riau (covering Riau Province, Riau Islands and West Sumatera)

3. Regional Division III Palembang Center Representative (covering Bengkulu, Jambi, Lampung, South Sumatera and Bangka Belitung Islands)

4. Regional Division IV Jakarta Central Representative (covering DKI Jakarta Province, part of Banten and part of West Java)

5. Regional Division V Representative Center of Bandung (covering Banten Province and West Java)

6. Regional Division VI of Central Semarang Representative (covering Central Java and Yogyakarta Provinces)

7. Regional Division VII Surabaya Center Representative (covering East Java Province)

8. Regional Division VIII Denpasar Representative Center (covering the Provinces of Bali, West Nusa Tenggara and East Nusa Tenggara)

9. Regional Division IX Representatives of the New Banjar Center (covering the Provinces of West Kalimantan, East Kalimantan, Central Kalimantan and South Kalimantan)

10. Regional Division X Representative of Makassar Center (covering Sulawesi and Maluku Provinces )

11. Regional Division XI Papua Central Representative (covering Papua and West Papua Provinces) 
The expansion of Pos Indonesia service area covers not only the Indonesian territory but also the international community. This international service allows Pos Indonesia to implement one of them to go international. Expansion of Pos Indonesia service area is done by establishing cooperation with business entity in other country which is international scale.

Pos Indonesia in serving its customers either on a national or international scale is not limited only in the pos, but also in the financial world. Money transfer facilities through Pos Indonesia can be enjoyed by its customers. Payment facilities for utility bills, water and telephones can be enjoyed at Pos Indonesia offices, including various disbursements of government compensation funds to the public. The various facilities offered in the implementation of Pos Indonesia to customers is a service management concept to meet customer needs.

Currently services conducted by Post Office of Indonesia by products and services include philately, post admail, express mail service, postal parcels, postal mail, logistics, cargo, bank channeling, fund distribution, postal giro and postal money orders. The service activities of the products and services provided by Pos Indonesia as the provider are expected to be able to realize the satisfaction of the service and increase the loyalty of the customer of postal service users. Indonesia Post Office Regional X Sulawesi and Maluku in carrying out their work can not be separated from various problems encountered, so it becomes an important phenomenon to be observed, especially related to the problem of decreasing the level of loyalty of postal service users due to the same business competition conducted by private companies also runs the same business between offering services of products and services through postal activity.

As a result of fierce competition with various offerings made by the competitors makes the post office is no longer a company that is monopolistic, but has become a competitive company. In general in the competitive business world, the company is developed and developed is a company that is able to increase customer loyalty by providing various convenience, fluency and certainty over all service activities of products and services provided. The fact that today's customers are no longer likely to make Post Office services a prime alternative, as customers can call or visit close, online, fleet-friendly business services and guarantee easy and fast service assurance. For example, a competitor outside the Post Office includes delivery service companies TIKI, JNE, Express, Fidex and others.

Trends in Post Office customer loyalty today, the loyalty rate is declining. This can be seen from the declining returning customers (repeatedly), the declining level of new subscribers based on the recommendation to continue subscribing, and the decreasing of the company's excellence in delivering corporate superiority ( say think positive ), this can be proved by the decrease of service information activity in Office Regional Post X Sulawesi and Maluku. The following shows the phenomenon of research that indicates the decline in customer loyalty levels seen from the percentage of repetitive service, the addition of new customers, and service innovation applied by the Post Office.

Table 1

Percentage Rate of Regional Post Offices X Sulawesi and Maluku Year 2012 - 2016

\begin{tabular}{|c|c|c|c|c|c|c|}
\hline \multirow{2}{*}{ Year } & \multicolumn{2}{|c|}{ Repeated Delivery } & \multicolumn{2}{c|}{ New Service Users } & \multicolumn{2}{c|}{ Service Innovation } \\
\cline { 2 - 6 } & Target & Realization & Target & Realization & Target & Realization \\
\hline 2012 & $>70 \%$ & $63.9 \%$ & $>80 \%$ & 71.6 & $>50 \%$ & 43.6 \\
2013 & $>70 \%$ & $62.4 \%$ & $>80 \%$ & 70.4 & $>50 \%$ & $30 \%$ \\
2014 & $>70 \%$ & $60.8 \%$ & $>80 \%$ & 68.9 & 38.6 \\
2015 & $>70 \%$ & $55.7 \%$ & $>80 \%$ & 67.3 & $>50 \%$ & 35.4 \\
\hline
\end{tabular}

Source: Regional Post Office X Sulawesi and Maluku, 2017 
Based on sources from Regional Offices X Sulawesi and Maluku 2016 above, informed that customer loyalty in the last five years decreased, referring to the realization of the repeat customer delivery rating, decreased from the predetermined target of the standard $>70 \%$, but the realization starting 2012 of $63.9 \%$ to $52.6 \%$ in 2016 . New service users are expected to increase also decrease from the predetermined target of the standard $>80 \%$, where the realization can only reach $71.6 \%$ in 2012 decreased until 2016 to $65.4 \%$. Similarly, the innovations made by Pos Indonesia also decreased from the target set ie the standard> 50\%, realization only reached $43.6 \%$ in 2012 and decreased to 20.8\% in 2016 (Regional Post X Sulawesi and Maluku, 2017) .

The management of the company's Post Office Regional X Sulawesi and Maluku realized the rate of decline in loyalty, by finding out the causes of customer loyalty decreased. Indications that lead to customer loyalty decline due to lack of satisfaction of customers due to the quality of services provided by the Pos Indonesia is unable to compete with other companies, and low corporate image with competitors in the same business.

Understanding this, then the issue of marketing management services become an important consideration to be addressed. Therefore, Tjiptono (2012: 49) stated that the success of the service business is determined by the increase of customer loyalty according to the fulfillment of the satisfaction, the improvement of the service quality and the improvement of the corporate image by the provider to the consumers. Consideration of this is the need to understand the theory of customer loyalty is the theory of loyalty ideas proposed by Lehtinen (2013: 15) that growing customer loyalty can not be separated from changing the idea of products and services to repeat buyers , reference recommends and say think positive .

This can not be applied properly by the Post Office of Indonesia to consider efforts to improve service user satisfaction, improve service quality and maintain corporate image to improve customer loyalty. The fact that is found for Pos Indonesia as a provider has not developed an orientation or prospective in favor of service user satisfaction in accordance with service quality and corporate image.

The company has been aware of the weaknesses, but the company has not been able to increase service user loyalty because the company has not been able to realize the satisfaction of service users. Seen in the reality of service activities undertaken by the company has not been able to manage complaints systems or suggestions from service users well, the company rarely conduct service user satisfaction surveys, no work team that has the initiative to do ghost shopping and the company rarely offer services back to users of perceived pos services. As a result the service users do not get the attention of the company in realizing the fulfillment of satisfaction.

The lack of consideration of the company in managing the fulfillment of service user satisfaction directly gives impact to the level of loyalty for pos services perceived so far. Management should be able to develop an understanding of satisfaction. According to Armstrong (2010: 82) that satisfaction becomes important to realize loyalty. The theory of customer satisfaction assessment according to Kotler (2013: 19) that there are four methods to measure customer satisfaction is to consider the system of complaints and suggestions, conducting customer satisfaction surveys, applying ghost shopping and contacting old customers. This method is effective for assessing satisfaction in growing user service loyalty.

Means the satisfaction and loyalty of service users in the concept of marketing services becomes an important consideration for the management to be managed in a priority and sustainable. Regardless of service quality considerations, Kotler and Keller (2012: 163) argue that the quality of service and corporate image is an important variavel to improve user satisfaction and loyalty products and services.

Research on satisfaction of service user loyalty among others is Chao-Chan Wu research (2011) there is positive and significant influence directly from customer satisfaction to customer loyalty. Research Monica Pricilia and Filter Abadi (2015) with the results of research that satisfaction directly has a positive and significant impact on customer loyalty. And Chi-Chuan Wu research, Shu-Hsien Liao, Yin-Ju Chen, Wei Lun Hsu (2011) with the results of customer satisfaction research affect customer loyalty.

For the Pos Indonesia company is currently trying to improve the quality of services in accordance with the ability, potential, image and trust offered to service users. The fact that service users understand the concept of service quality is only oriented towards the realization of tangible service quality, empathy, reliability, responsive and assurance. The quality of this service in the form of services received from the provider (the Pos Indonesia) to 
the service user (customer) is the quality of tangible service provision that is the availability of counter service, post delivery fleet, ready employees and limited infrastructure facilities. Service quality of empathy (empathy) that service users want the company to understand the demands of customers, listening to complaints, provide a means for complaints, providing information procedures and mechanisms for the prompt service.

Quality of service reliability (reliability) also highly expected by service users to quickly serve, quickly provide information, timely delivery and professional introduction. The responsiveness of the customer's desired service is to respond to new innovations, encourage strong teamwork, and be able to solve technical problems and not to charge the service user. Quality of service assurance (assurance) desired by service users that is to ensure security, damage, loss and provide compensation for services that are not appropriate.

Consideration of the quality of service applied so far from the company Pos Indonesia Regional X Sulawesi Maluku often neglected by the orientation of efficiency, savings and budgetary constraints, so that the company is only able to provide services as necessary that tend to affect customer satisfaction and loyalty, as lost to competitors who move in the same field. Due to the quality of services that are less qualified leads to user satisfaction and loyalty automatically decreases. This is a consideration that needs to be addressed by the company.

Parasuraman (2004: 69) suggests the service quality theory that quality service is a consideration for customers to fulfill customer satisfaction and loyalty. The elements of quality presented Parasuraman consist of quality of physical evidence ( tangible ), emphathy ( empathy), reliability ( reliability), responsiveness ( responseiveness ) and assurance (assurance). This is an important consideration for the realization of customer satisfaction and loyalty which is currently a problem faced by Pos Indonesia Regional X Sulawesi Maluku.

Here are some of the results of previous research that have observed or examined the effect of service quality on satisfaction and loyalty among others, Ren-Fang Chao, Tai-Chi Wu, I-Shou and Wei-Ti Yen (2015) with the result of quality service research have positive influence to customer satisfaction. The study of Hamad Saleem and Naintara Sarfraz Raja (2014) with the results of quality service research influenced customer satisfaction. The research of Muhammad Ehsan Malik, Muhammad Mudasar Ghafoor and Hafiz Kashif Iqbal (2012) with the results of quality service and price research have an effect on customer satisfaction. Researches that examine service quality for service user loyalty include Genoveva research (2015) found that there is a negative and insignificant effect of perception of service quality on customer loyalty.

In addition, given the increasingly tight competition of the postal service business, in which companies engaged in the same field seeks to improve the image of the company. Companies such as JNE, TIKI, Express, Fidex and others, are now competing to seize consumers by expanding and concentrating on improving their corporate image, so consumers will choose various shipping business alternatives as competitors from Pos Indonesia Regional X Sulawesi Maluku. Therefore the management must take the decision to improve and improve the reputation of the company image.

The phenomenon that became reality shows that the image of the company Pos Indonesia Regional Office X Sulawesi Maluku today there is a tendency to compete with companies in the same field. It can be seen from the image of the company owned by the company in terms of quality of products and services provided is different in quality packaging compared to other companies, in terms of services provided by other companies more professional serving than the Post Office Indonesia, management policy Pos Indonesia too sided with the demands of excellent service compared to other companies that have put forward the policy of subsidy to the customer. Judging from the reputation shown by the Pos Indonesia company, the success trend has not improved much compared to other companies' success trends to serve the whole of Indonesia and abroad quickly. The Indonesian Postal Company in developing the marketing activities lacked innovative transformation of products and services compared to other companies in marketing activities is quite innovative to transform the packaging of products and services.

This is a description of the image of the company that has not been actualized optimally done by the Post Office compared to other companies engaged in the same business, so it is necessary consideration to use the theory of corporate image formation from Kerby (2004: 57) that to win the competition of products and services in realizing customer satisfaction and loyalty required the formation of corporate image. The image of the company is built on 1) the quality of the products produced; 2) services provided; 3) company policy; 4) company reputation; 
and 5) the company's marketing activities. These five indicators are important to realize customer satisfaction and loyalty.

The results of previous research that have observed the correlation between the influence of corporate image on customer satisfaction and loyalty are Ren-Fang Chao, Tai-Chi Wu, I-Shou and Wei-Ti Yen (2015) with the result of corporate image research giving positive and significant influence to the satisfaction . The research of Muhammad Ehsan Malik, Muhammad Mudasar Ghafoor and Hafiz Kashif Iqbal (2012) with the result of research of corporate image have an effect on to customer satisfaction. Monica Pricilia and Filter Abadi (2015) research finds company image to give positive and significant influence to loyalty. Research Yu Te Tu, Mei Lien Li, Chi Chi Chi (2013) with the results of corporate image research have a positive and significant impact on customer loyalty.

Understanding the description of the phenomenon, facts based on data and previous research results become the foundation for researchers to interested in researching by choosing the title: Influence Service Quality and Corporate Image on Satisfaction and Loyalty of Postal Service Users in Regional X Sulawesi and Maluku.

\section{Literature Review and Hypothesis Testing}

In this study there are four observed variables consisting of two exogenous variables and two endogenous variables. Exogenous variables in this study consist of service quality and corporate image. While the endogenous variables in the form of a variable between that satisfaction as well and the dependent variable is loyalty.

\section{Quality of Service}

Quality of service refers to the service quality theory of Parasuraman (2004: 69) suggests the concept of quality of service that quality services into consideration for service users to meet the satisfaction and loyalty of service users. The quality of service is in the form of physical evidence (tangible), kemampupahaman (empathy), quality reliability (reliability), responsiveness (responsiveness) and assurance (assurance) .

H1 The quality of service directly affects positively and significantly to the satisfaction of postal service users in Regional X Sulawesi and Maluku .

H 3 The quality of services directly positively and significantly affects postal service users' loyalty in Regional X Sulawesi and Maluku .

H6 Quality of service through satisfaction has a positive and significant impact on postal service user loyalty in Regional X Sulawesi and Maluku.

\section{Corporate Image}

Corporate image refers to the theory of corporate image formation from Kerby (2004: 57) that to win the competition of products and services in realizing customer satisfaction and loyalty required the formation of corporate image. The image of the company is built on 1) the quality of the products produced2) the services provided; 3) company policy; 4) company reputation; and 5) the company's marketing activities .

H2 Corporate image directly affects positively and significantly to postal service user satisfaction in Regional X Sulawesi and Maluku .

H 4 Corporate image directly affects positively and significantly to postal service user loyalty in Regional X Sulawesi and Maluku .

H7 Corporate image through satisfaction has a positive and significant impact on postal service user loyalty in Regional X Sulawesi and Maluku.

\section{Satisfaction}

Satisfaction refers to Kotler service satisfaction assessment theory (2013: 19) that there are four methods to measure the satisfaction of service users that are considering complaints and suggestions system, conducting service user satisfaction survey, applying ghost shopping and contacting old service users. 


\section{Loyalty}

Loyalty refers to Griffin's theory of loyalty assumption (2005: 36) that judging loyal or disloyal service users is seen from the loyalty of repurchasing regularly, always recommending references of experience to others for services received and showing a positive response to the services offered .

H 5 Satisfaction directly affects positively and significantly to postal service user loyalty in Regional X Sulawesi and Maluku.

\section{Research methods}

This study was designed to answer the problems that have been formulated and the objectives to be achieved and to test the hypothesis. The location of the research was conducted at Pos Indonesia Regional X Sulawesi and Maluku as research object to see the influence of service quality and corporate image to the satisfaction and loyalty of postal service user at Pos Indonesia Regional X Sulawesi and Maluku. The study time is scheduled for three months from April to June 2017. There are two types of research that is quantitative and qualitative research. Sources of data in this study consisted of primary and secondary data. Data collection techniques (instruments) used are observations, questionnaires, interviews and documentation. The population in this study were all service users of Pos Indonesia Regional X Sulawesi and Maluku who used postal service during 2017. Determination of sample is done by using quota sampling method. Researcher determined by purposive as many as 5,540 service users of postal service that do service at Post Office, then researcher use 5\% quota sampling as respondents research. Determination of sample quota of researchers conducted by accidental sampling according to the desire of postal service users who are willing to be respondents, so that the total samples totaled 5,540 users of postal services, and after the quota sampling method 5\% 277 respondents . Data analysis techniques used in explaining the phenomenon in this research is descriptive statistical analysis techniques and analysis of Structural Equation Modeling (SEM).

\section{Analysis and Discussion}

Testing of this first model is grouped into exogenous variables (exogenous variables) and endogenous variables (endogenous variables). Exogenous variable is a variable whose value is determined outside the model. While the endogenous variable is a variable whose value is determined through the equation or from the established relationship model. Included in the group of exogenous variables is the measurement of service quality and corporate image, while the endogenous variable is the satisfaction and loyalty of postal service users. The model is said to be good when the hypothetical model development is theoretically supported by empirical data. The result of SEM analysis can be seen in the following figure: 


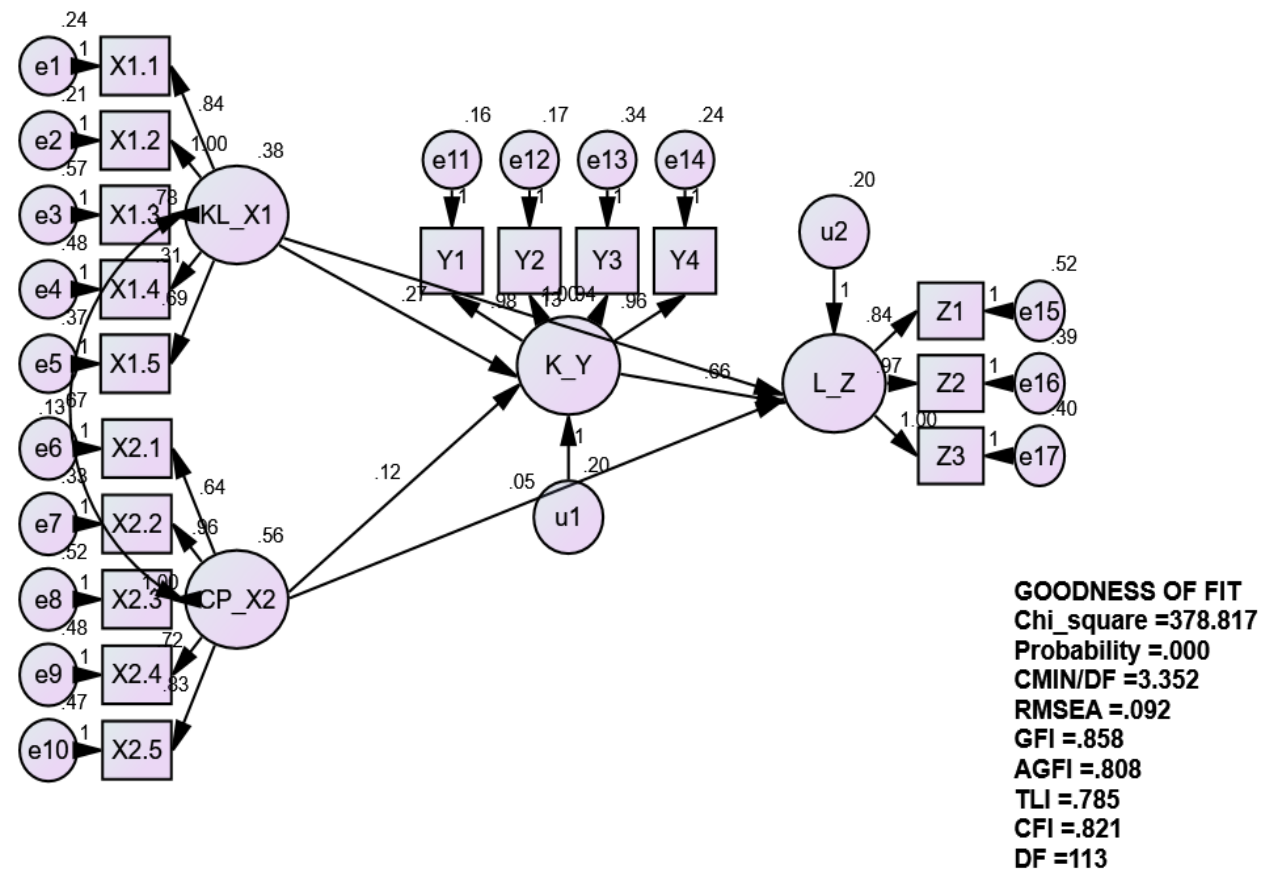

Figure 1

Measurement of Variable Relation Models for Early SEM

From the evaluation model shows that the eight criteria of goodness of fit indices show that the chisquarenya value is still big and some criteria do not match the cut off value determined, so modification of the model is done by correlation between the error indicator according to the instructions of modification indices. Results of analysis after the final model obtained are as follows:

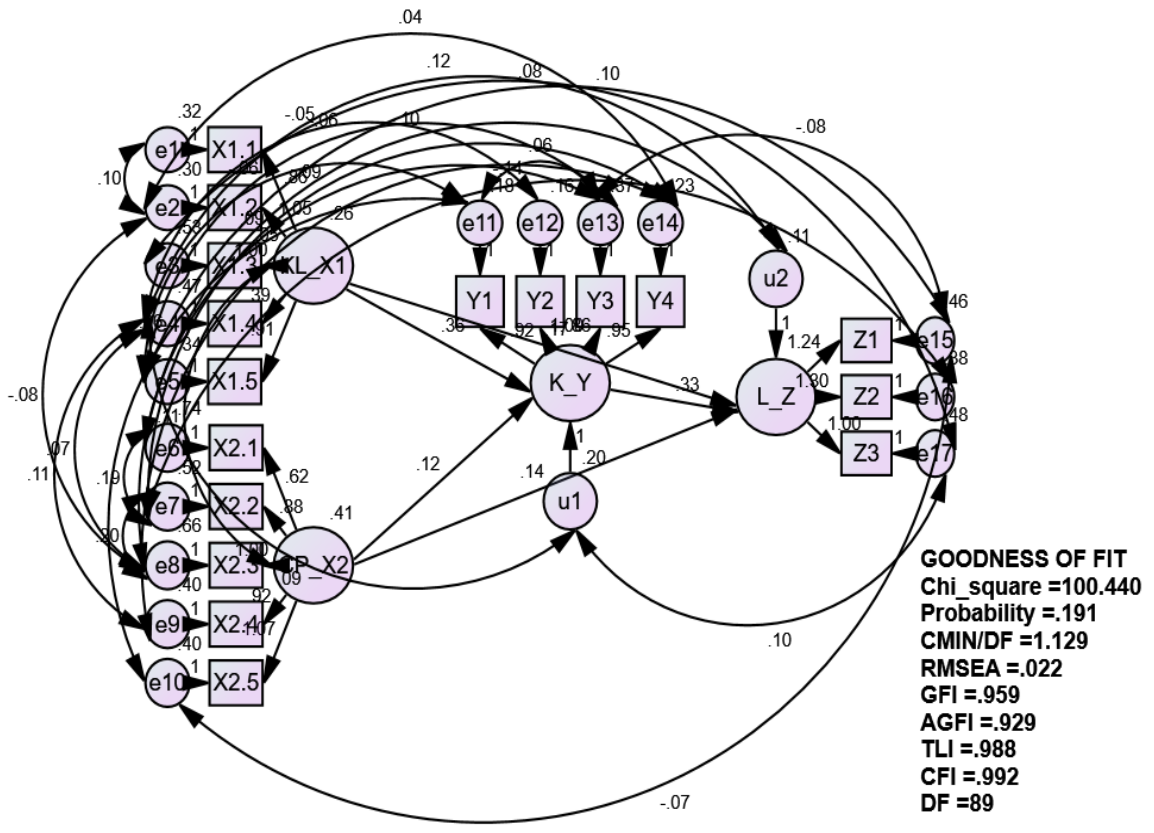

Figure 2

Measurement of Variable Relationship Models un SEM End 
The model test results presented in Figure 2 are evaluated based on the goodness of fit indices in Table 2 with the presented criteria model and its critical value that have data conformity.

Table 2

Evaluation of Goodness of Fit Indices criteria Overall Model

\begin{tabular}{|c|c|c|c|c|c|}
\hline $\begin{array}{c}\text { Goodness of } \\
\text { fit index }\end{array}$ & $\begin{array}{c}\text { Cut-off } \\
\text { Value }\end{array}$ & $\begin{array}{c}\text { Model Results } \\
\text { Early stage }\end{array}$ & Ket. & $\begin{array}{c}\text { Model Results } \\
\text { Final Stage }\end{array}$ & Ket. \\
\hline Chi_Square & $\begin{array}{c}\text { Expected } \\
\text { small }\end{array}$ & 378.817 & Marginal & 100440 & Good \\
\hline Probability & $\geq 0.05$ & 0.000 & Marginal & 0.191 & Good \\
\hline CMIN / DF & $\leq 2.00$ & 3.352 & Marginal & 1.129 & Good \\
\hline RMSEA & $\leq 0.08$ & 0.092 & Marginal & 0.022 & Good \\
\hline GFI & $\geq 0.90$ & 0.858 & Marginal & 0.959 & Good \\
\hline AGFI & $\geq 0.90$ & 0.808 & Marginal & 0.929 & Good \\
\hline TLI & $\geq 0.94$ & 0.785 & Marginal & 0.988 & Good \\
\hline CFI & $\geq 0.94$ & 0.821 & Marginal & 0.992 & Good \\
\hline \multicolumn{2}{|r|}{} & 113 & & 89 & \\
\hline
\end{tabular}

Source: Data after processed

The result of model evaluation for the early stage shows that the eight goodness of fit indices criteria have not met the criteria of cut off value, starting from Chi-Square, proability, CMIN / Df, RMSEA, GFI, AGFI, TLI and CFI, with instructions from modification indices. Modification Indices ( MI) is a calculation to make changes to the numbers, where the numbers below indicate the minimum value of chi-square that will fall if the corresponding variable is connected. After the modification of the model, the final stage shows the eight criteria of goodness of fit indices have met the criteria or according to cut off value, so that the model is said to have been in accordance with the criteria of goodness of fit indices for the analysis.

Based on the empirical model proposed in this study can be tested against the hypothesis proposed through the testing of path coefficients in the model of structural equations. Table 3 is a hypothesis testing by looking at the value of $\mathrm{p}$ value, if the value of $\mathrm{p}$ value is less than 0.05 then the relationship between the significant variables. It also explains the direct effect (direct effect) means there is a direct positive influence between the variables, indirect effect (indirect effect) means there is an indirect positive influence between the variables, and the total effect (total effect) is the accumulation of direct influence and indirectly. Test results are presented in the following table:

Table 3

Hypothesis Testing of Direct Effect and Indirect Effect

\begin{tabular}{|c|c|c|c|c|c|c|c|}
\hline \multirow{2}{*}{ HIP } & \multirow{2}{*}{$\begin{array}{c}\text { Independent } \\
\text { Variables }\end{array}$} & Dependent Variables & $\begin{array}{c}\text { p- } \\
\text { value }\end{array}$ & DE & IE & TE & Information \\
\hline H1 & $\begin{array}{c}\text { Quality of Service } \\
\text { (X1) }\end{array}$ & Satisfaction (Y) & 0.000 & 0.368 & - & 0.368 & $\begin{array}{c}\text { Positive and } \\
\text { Significant }\end{array}$ \\
\hline H 2 & $\begin{array}{c}\text { Corporate Image } \\
\text { (X2) }\end{array}$ & Satisfaction (Y) & 0.043 & 0.158 & - & 0.158 & $\begin{array}{c}\text { Positive and } \\
\text { Significant }\end{array}$ \\
\hline H 3 & $\begin{array}{c}\text { Quality of Service } \\
\text { (X1) }\end{array}$ & Loyalty (Z) & 0.044 & 0.199 & - & 0.199 & $\begin{array}{c}\text { Positive and } \\
\text { Significant }\end{array}$ \\
\hline
\end{tabular}




\begin{tabular}{|c|c|c|c|c|c|c|c|c|}
\hline $\mathrm{H} 4$ & $\begin{array}{c}\text { Corporate Im } \\
(\mathrm{X} 2)\end{array}$ & \multicolumn{2}{|c|}{ Loyalty (Z) } & 0.016 & 0.206 & - & 0.206 & $\begin{array}{c}\text { Positive and } \\
\text { Significant }\end{array}$ \\
\hline H 5 & Satisfaction (Y) & \multicolumn{2}{|c|}{ Loyalty (Z) } & 0.000 & 0.392 & - & 0.392 & $\begin{array}{c}\text { Positive and } \\
\text { Significant }\end{array}$ \\
\hline & $\begin{array}{c}\text { Independent } \\
\text { Variables }\end{array}$ & $\begin{array}{c}\text { Intervening } \\
\text { Variables } \\
\end{array}$ & $\begin{array}{c}\text { Dependent } \\
\text { Variables }\end{array}$ & $\begin{array}{c}\text { p- } \\
\text { value }\end{array}$ & DE & IE & $\mathbf{T E}$ & Information \\
\hline H6 & $\begin{array}{c}\text { Quality of } \\
\text { Service (X1) }\end{array}$ & $\begin{array}{l}\text { Satisfaction } \\
(\mathrm{Y})\end{array}$ & Loyalty (Z) & 0.043 & 0.199 & 0.144 & 0.343 & $\begin{array}{c}\text { Positive and } \\
\text { Significant }\end{array}$ \\
\hline $\mathrm{H} 7$ & $\begin{array}{l}\text { Corporate } \\
\text { Image (X2) }\end{array}$ & $\begin{array}{l}\text { Satisfaction } \\
\text { (Y) }\end{array}$ & Loyalty (Z) & 0.086 & 0.206 & 0.062 & 0.268 & $\begin{array}{c}\text { Positive and } \\
\text { No } \\
\text { Significant }\end{array}$ \\
\hline
\end{tabular}

Source: Appendix 8

To see the result of $\mathrm{p}$-value $\mathrm{v}$ on indirect effect of independent variable through intermediate variable to dependent variable following result of calculation of test of Sobel:

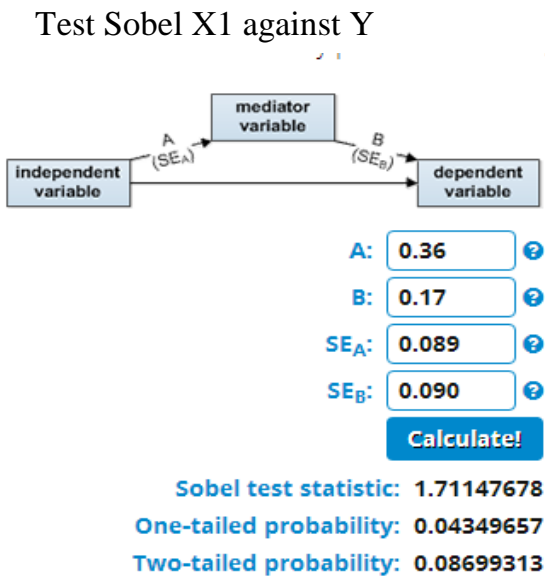

Test Sobel X2 against Z

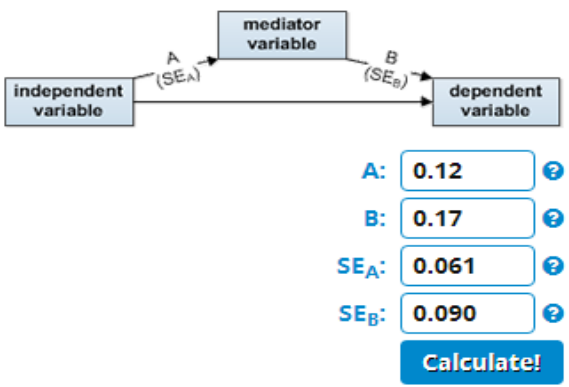

Sobel test statistic: $\mathbf{1 . 3 6 2 4 9 4 4 4}$

One-tailed probability: 0.08652095

Two-tailed probability: $\mathbf{0 . 1 7 3 0 4 1 9 0}$

Of the overall model of five straight lines and two indirect pathways hypothesized, looks entirely positive and significant influence. The interpretation of Table 3 can be explained as follows:

1. The quality of service has a positive and significant direct effect on the satisfaction of postal service users with $p=0,000<0.05$ and coefficient value of 0.368 , this coefficient indicates that the quality of service received is good and provide satisfaction for postal service users. Seen in Table 17, the dominant service quality indicator of its contribution is the second indicator with a loading factor of 1,000 (fix) and the smallest contribution is the fourth indicator with the loading factor of 0.257 . The second indicator is empathy where the attitude of care in every service is very important for postal service users. The fourth indicator is the responsiveness, in which the postal service user is expecting a service that quickly gets a response. Pressure on the results is what triggers service quality variables to be positive and significant to the satisfaction of postal service users. This is supported by the research of Ren-Fang Chao, Tai-Chi Wu, IShou and Wei-Ti Yen (2015) with the results of quality service research have a positive and significant impact on satisfaction.

2. Corporate image has a direct positive and significant influence on the satisfaction of postal service users with $p=0.043<0.05$ and coefficient value by 0158 , this coefficient indicates that the image shown is good company and provide satisfaction for users of postal services. In Table 17 indicators of the company's image is the dominant contribution to the third indicator with a loading factor of 1.000 (fix) and the smallest contribution is the first indicator of the loading factor 0656 . The third indicator is the policy of the company as a rule patents on products / services that can be enjoyed by users of postal services. The first 
indicator is the quality of products / services that are still to be upgraded. Pressure on the results of the variable that triggered a positive company image and significant impact on user loyalty postal services. This is supported by research Ehsan Malik, Hafiz Muhammad Mudasar Ghafoor and Kashif Iqbal (2012) with the results of the company's image and significant positive effect on customer satisfaction .

3. The quality of service has a direct positive influence and significant impact on user loyalty postal services by $p=0.000>0.05$ and a coefficient of 0368 , this coefficient indicates that the quality of service received has been good and give loyalty to users of postal services. Shown in Table 17, an indicator of the quality of service of the dominant contribution is the second indicator with a loading factor of 1,000 (fixed) and the smallest contribution is the fourth indicator with loading factor 0257. The second indicator is empathy where caring attitude in every service is very important for users of postal services. The fourth indicator is the responsiveness, where the postal service is expecting quick service response. Pressure on the results that triggered the variable quality of service to be positive and significant impact on user loyalty postal services. This is supported by studies Ren-Fang Chao, Tai-Chi Wu, I-Shou and Wei-Ti Yen (2015) with the results of the quality of services and significant positive effect on loyalty .

4. The image of the company has a direct positive influence and significant impact on user loyalty postal services by $p=0.043>0.05$ and a coefficient of 0158 , this coefficient indicates that the image shown is good company and give loyalty to users of postal services. Table 17 shows the indicators of the dominant image of the company contribution is a third indicator to the loading factor of 1.000 (fix) and the smallest contribution is the first indicator of the loading factor 0656. The third indicator is the policy of the company as a rule patents on products / services that can be enjoyed by users of postal services. The first indicator is the quality of products / services that are still to be upgraded. Pressure on the results of the variable that triggered a positive company image and significant impact on user loyalty postal services. It is powered by Monica Pricilia and Filter Eternal (2015) found the image of the company provide a significant and positive effect on loyalty .

5. Satisfaction has a direct positive influence and significant impact on user loyalty postal services by $\mathrm{p}=$ $0.000>0.05$ and a coefficient of 0392, this coefficient indicates that customer satisfaction has been actualized, so that users of postal services menunjukka loyalty. Shown in Table 19, the dominant contribution to the satisfaction indicator is an indicator of both the loading factor of 1,000 (fixed) and the smallest contribution is the third indicator with loading factor 0.930 . The first indicator is the system of complaints and suggestions provided by the postal authorities in accommodating complaints and suggestions of the users of postal services. The third indicator is the ghost shopping by hiring people to observe the potential services that apply to users of postal services. Pressure on the results of the variable that triggered the satisfaction to be positive and significant impact on user loyalty postal services. This is supported by studies Chao-Chan Wu (2011) there is a positive and significant influence directly from satisfaction to customer loyalty .

6. The quality of service through satisfaction has a direct positive influence and significant impact on the postal service user loyalty with coefficient indirect effect by 0144. Results of the calculations through Sobel test ( Sobel test) was obtained for $1,711<1.98$ with a significance level of $\mathrm{p}=0.043<0.05$, proving that indirectly any quality of service through customer satisfaction and significant positive effect on loyalty users of postal services, but the quality of service applied not maximized. This means the satisfaction intervening variables still need to be improved, so as to mediate the quality of service to the loyalty of users of postal services.

7. Corporate image through the satisfaction of having a positive indirect effect and no significant effect on the postal service user loyalty with coefficient indirect effect by 0062. Results of the calculations through Sobel test ( Sobel test) was obtained for $1,362<1.98$ with a significance level of $\mathrm{p}=0.086>0.05$, proving that indirectly any company's image through positive influence satisfaction and loyalty is not significant to users of postal services. This means intervening variables are not able to mediate satisfaction of the company's image to the loyalty of users of postal services.

Based on Table 3 it can be seen that there is a ten track all significant influence. Thus the hypothesis:

H1 : Affect service quality postal service user satisfaction

H2 : Corporate image affects user satisfaction of postal services

H3 : The quality of service affects the loyalty users of postal services

H4 : Corporate image affects user loyalty postal services

H5 : Satisfaction affects the loyalty of users of postal services 
H6 : The quality of service through satisfaction affects loyalty of users of postal services

Empirical data supported the hypothesis is accepted

H7 : Corporate image through the satisfaction affects loyalty of users of postal services

\section{No empirical data supported the hypothesis is rejected}

Analysis of direct influence (direct effect), the indirect effect (indirect effects), and the total effect (total effects) between variables in the model, used to compare the effect of each variable constructs. The direct effect is the coefficient of all coefficients lines with arrows one end, while the indirect effect is an effect that arises through an intermediate variable (intervening variable), while the total effect is the effect of the various relationships (Ferdinand, 2000: 139). Influence test results are presented in Table 20 which shows the influence of direct, indirect and total influence between variables.

\section{Conclusion}

Based on the analysis and discussion of the results of research on the Regional Post Office X Sulawesi and Maluku, summarized as follows: 1) Quality of service is positive and significant impact on the postal service user satisfaction. Actualization of the services applied post office has been able to realize the satisfaction of the users of postal services in getting quality services; 2) The image of the company and significant positive effect on the postal service user satisfaction. The impression on the products / services that give interest to use the services at post offices improve the satisfaction of users of postal services ; 3) Quality of service is positive and significant impact on user loyalty postal services. The realization of quality services increase the loyalty of its customers to use the postal service ; 4) The image of the company and significant positive effect on loyalty postal service users. Corporate image gives a good image in building customer loyalty using the postal service ; 5) Satisfaction positive and significant effect on the loyalty of users of postal services. Good feelings using the postal service as the actualization of the attitude of loyalty shown postal service users ; 6) The quality of service through customer satisfaction and significant positive effect on loyalty postal service users. Actualization quality services capable of providing satisfaction for any postal service, so that users of postal services remain consistent to use the postal service in shipping goods / documents; and 7) The image of the company through customer satisfaction and no significant positive effect on loyalty postal service users. Loyalty users of postal services is not determined by the company's image, so that the level of user satisfaction of postal services can not mediate in realizing the postal service user loyalty.

\section{References}

[1] Abdelsalam Adam Hamid, Balal Siddig Ibrahim, Abdelmonim Shawgi Seesy, Ali Abdel Hafiez Hasaballah, 2015. Interaction Effect of Perceived Service Quality and Image Image On Customer Satisfaction. Asian Journal of Management Science, 03 (10), 2015.

[2] E Anca Cretu and Roderick J Brodie, 2007. The Influence of Image Image and Company Reputation Manufactures Markets to Small Firms: A Customer Value Perception. Industrial Marketing Management 36 (2007) 230 - 240.

[3] Tat Chan Huei Lim Aik Nai Yet Mee and Chiek, 2015. A Study of Image Image, Perceived Service Quality, Patient Satisfaction and Behavioral Intention among the Medical Tourism. Global Journal of Business and Social Science Review ISSN 2289-8506 Vol. 2 (1), April-June, 2015.

[4] Chan Chao-Wu, 2011. The Impact of Hospital Image Image on Service Quality, Patient Satisfaction and Loyalty. African Journal of Business Management Vol. 5 (12), pp. 4873-4882, 18 June 2011 Available online at http://www.academicjournals.org/AJBM DOI: 10.5897 / AJBM10.1347 ISSN 1993-8233 @ 2011 Academic Journals.

[5] Chi-Chuan Wu, Shu-Hsien Liao, Yin-Ju Chen, Wei Lun Hsu, 2011. Service Quality, Image Image and Price Fairness Impact on the Customer Satisfaction and Loyalty. 978-1-4577-0739-1 / 11 / \$ 26.00 ( 2011 IEEE.

[6] Eman Mohamed Abd El Salam, Ayman Shawky and Tawfik Yehia El-Nahas, 2013. The impact of corporate image and reputation on service quality, customer satisfaction and customer loyalty: testing the mediating role. Case Analysis in an international service company. The Business \& Management Review, Vol.3 Number 2, January, 2013.

[7] Genoveva, 2015. Analyzing of Customer Satisfaction and Customer Loyalty Based on Image Image and Perceived Service Quality. Journal of US-China Public Administration, June 2015, Vol. 12, No. 6, 497-508 doi: 10.17265 / 1548 $6591 / 2015.06 .008$. 
[8] Hamad Saleem and Naintara Sarfraz Raja, 2014. The Impact of Service Quality on Customer Satisfaction, Customer Loyalty and Image Image: Evidence from the Hotel Industry of Pakistan. Middle-East Journal of Scientific Research 19 (5): 706-711, 2014. ISSN 1990-9233 @ IDOSI Publications, 2014 DOI: 10.5829 / idosi. mejsr.2014.19.5.21018.

[9] Kerby, RH., 2004. Principles of Image Image Marketing . $10^{\text {th }}$ ed. Published of Prentice Hall, New Jersey .

[10] Kotler, Philip, 2013. Marketing Management: Analysis, Planning, Implementation, and Control , 9 th ed. Englewood Cliffs, NJ: Prentice-Hall International, Inc.

[11] Kotler, Philip and Gary Armstrong, 2010. Principles of Marketing, 6th ed. Englewood Cliffs, NJ: Prentice-Hall International, Inc.

[12] Kotler, P., \& Keller, KL, 2010. Principles of Marketing . $10^{\text {th }}$ ed. Published of Prentice Hall, New Jersey .

[13] Kum-Hsi Liao, 2012. The Casual Effect of Service Quality, Image Image, Customer Satisfaction on Customer Loyalty in the Leisure Resot Enterprise. China-USA Business Review, May 2012 ISSN 1537-1514 Vol. 11 No. 5, 631-642.

[14] Lehtinen, 2013. The Essence of Service Marketing, Andi Yogyakarta

[15] Monica Pricilia and Filter Abadi, 2015. Analyzing the Affect of Image Image, Service Quality and Customer Satisfaction toward Customer Loyalty in a Premium Coffeehouse Retailer, Case of Starbucks Indonesia in Tangerang Area. Proceedings of the International Conference on Innovation, Entrepreneurship and Technology 25 to 26 November 2015, the BSD City , Indonesia ISSN: 2477-1538.

[16] Muhammad Ehsan Malik, Hafiz Muhammad Mudasar Ghafoor and Kashif Iqbal, 2012. Impact of Image Image, Service Quality and Price on Customer Satisfaction in Pakistan Telekomunication Sector. International Journal of Business and Social Science Vol. 3 No. December 23, 2012.

[17] Muhammad Ehsan Malik, Basharat Naeem and Abdul Mohsin Nasir, 2011. Impact of Service Quality on Image Image: Empirical Evidence from the Hotel Industry. Ijcrb.webs.com. Vol. 3 No. 8 December, 2011.

[18] Parasuraman, A. Valerie, 2004. Delivering Quality Service. The Free Press, New York . (Translated by Sutanto).

[19] Ren-Fang Chao, Tai-Chi Wu, I-Shou and Wei-Ti Yen, 2015. The Influence of Service Quality, Image Image, and Customer Satisfaction on Customer Loyalty for Private Karaoke Roomsin Taiwan . The Journal of Global Business Management Volume $11 *$ Number $1 *$ April 2015 Issue.

[20] Yulia Irani Siti Nugraha, Sukarno Wibowo, Harry Soeparman, 2012. Analysis of the Effect of Service Quality to the Customer Satisfaction and Image Image in the Enhaii Restaurant. International Journal of Science and Research. ISSN (Online): 2319-7064 Impact Factor (2012): 3358.

[21] Tawan Vigripat and Peng Chan, 2007. An Empirical Investigation of the Relationship Between Service Quality, Image Image, Trust, Customer Satisfaction, Repurchase Intention and Recommendation to Others. International DSI / Asia and Pacific DSI 2007 Full Paper (July 2007).

[22] Tjiptono, Fandy, 2012. Principles of Marketing, Eighth Edition, Damos Bahada Sihombing Rather, the publisher, Jakarta .

[23] Yu Te Tu, Mei Lien Li, Heng Chi Chili, 2013. An Empirical Study of Corporate Image Image, Customer Perceived Value and Satisfaction on Loyalty in Shoe Industry. Journal of Economics and Behavioral Studies. Vol. 5, No. 7, pp. 469-483, July 2013 (ISSN: 2220-6140).

[24] Zeithaml, Valarie A., 2001. Service Quality, Profitability, And The Economic Worth Of Costumers: What We Know and What We Need To Learn. Journal Of The Academy Of Marketing Sciences 28 (1): 67_85.

[25]Zeithaml, Valarie and Bitner, A., 2001. The Behavioral Consequencies Of Service Quality, Journal of Marketing , 60 (2): 31-46. 